\title{
The fitoaty: an unidentified carnivoran species from the Masoala peninsula of Madagascar
}

\author{
Cortni Borgerson
}

\author{
University of Massachusetts \\ Department of Anthropology \\ Amherst, U.S.A. \\ E-mail: cortni@anthro.umass.edu
}

\begin{abstract}
Little is known about carnivoran ecology and population dynamics in northeastern Madagascar, especially on the little studied Masoala peninsula. This leaves the status of threatened carnivores on the Masoala peninsula poorly understood. Even less is known about the relative taxonomic position and role of domestic, feral, and possible wild cats in Madagascar. Adequate conservation of the Masoala peninsula will remain limited until the status, threats, and roles of felines and native carnivorans in regional system dynamics are documented. Six of the ten carnivoran species belonging to the endemic family Eupleridae, as well as introduced civets, domestic dogs, and cats are known to exist on the peninsula. This paper reports an animal of unknown identity in the Masoala carnivoran assemblage, the fitoaty. specifically it, (i) reports preliminary observations on the fitoaty collected on the Masoala peninsula, and (ii) describes fitoaty distribution and habits based on local knowledge. Fitoaty appear to have a broad geographic range on the peninsula and to prefer contiguous forests near and within the Masoala National Park. The author tentatively identifies the fitoaty as Felis sp. but extensive carnivoran trapping and genetic testing of the fitoaty are needed to adequately assess the range and identity of this carnivoran and its potential impact on local ecosystems.
\end{abstract}

\section{RÉSUMÉ}

L'écologie et la dynamique des populations de carnivores du Nord-est de Madagascar sont mal connues, plus particulièrement sur la presqu'île Masoala qui a été peu étudiée. Ce manque de connaissances empêche de statuer sur le degré de menace auquel font face les carnivores de la presqu'île. II en est de même de la position taxinomique et du rôle écologique des chats domestiques et sauvages à Madagascar. La conservation de la presqu'île Masoala finira par pêcher tant que le statut, les menaces et les rôles des félins et des carnivores autochtones ne seront pas documentés dans la dynamique régionale. Parmi les dix espèces de carnivores appartenant à la famille endémique des Eupleridae, six sont connues de la presqu'île Masoala. La civette allochtone, les chiens domestiques et des chats ont également été recensés sur la presqu'île. Cet article décrit un animal d'une identité inconnue de la communauté des carnivores de la presqu'île Masoala, le fitoaty. Plus spécifiquement, il présente l'observation d'un carnivore non identifié par I'auteur d'une part et les résultats d'une évaluation indirecte à travers des enquêtes villageoises portant sur la présence de cet animal sur la presqu'île Masoala, d'autre part. À l'exception de sa grande taille (avec un poids estimé à 3-4 kg), d'une musculature développée, d'un pelage noir uniforme, court et brillant, et de ses yeux rouge-orangé, la morphologie du fitoaty rappelle celle d'un chat domestique. II semblerait que le fitoaty serait distribué sur une vaste étendue géographique de la presqu'île Masoala. Contrairement aux chats sauvages rencontrés ailleurs à Madagascar, le fitoaty semble préférer les forêts du Parc National de Masoala et de ses environs. Même dans les villages où le fitoaty a été vu à de nombreuses reprises, il est considéré comme rare. Le fitoaty est provisoirement identifié comme une espèce de félins, à savoir Felis sp. mais une appartenance spécifique dépendra des résultats d'un programme de capture des carnivores et du dépistage génétique du fitoaty qui permettra également d'évaluer sa distribution et son impact éventuel sur les systèmes locaux. Dans la mesure où la presqu'île Masoala abrite l'un des derniers grands blocs de forêt humide de basse altitude à Madagascar et que les carnivores allochtones sont connus pour leurs impacts négatifs sur les espèces autochtones de Madagascar, il est indispensable de vérifier rapidement ce qu'il en est de l'identité, de la distribution et de l'impact écologique du fitoaty.

\section{INTRODUCTION}

The Masoala peninsula is home to one of Madagascar's largest and most remote national parks and contains some of the greatest biodiversity within all of Madagascar (Kremen et al. 1999, Kremen 2003). However, the same geographical features that have played a role in protecting the peninsula's biodiversity from anthropogenic disturbances (i.e., its wet rugged terrain, large size, and relative isolation) have also left it poorly studied. The limited knowledge about carnivoran ecology and population dynamics in northeastern Madagascar (Farris et al. 2012, Hawkins 2012) leaves the status of threatened carnivores on the Masoala peninsula poorly understood. Adequate conservation of the peninsula will also remain limited until the status, threats, and roles of carnivores in regional system dynamics are clarified. Six of the ten carnivore species within the endemic family Eupleridae (Yoder et al. 2003), (Cryptoprocta ferox [locally known as: fôsa, common name: fosa], Eupleres goudotii goudotii [falanoka, small-toothed civet], Fossa fossana [tombokantsodina, Malagasy civet], Galidia elegans [vontsira- 


\section{vOLUME 8 ISSUE 2

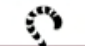 NOVEMBER 2013 MADAGASCAR 5,8 CONSERVATION \& DEVELOPMENT}

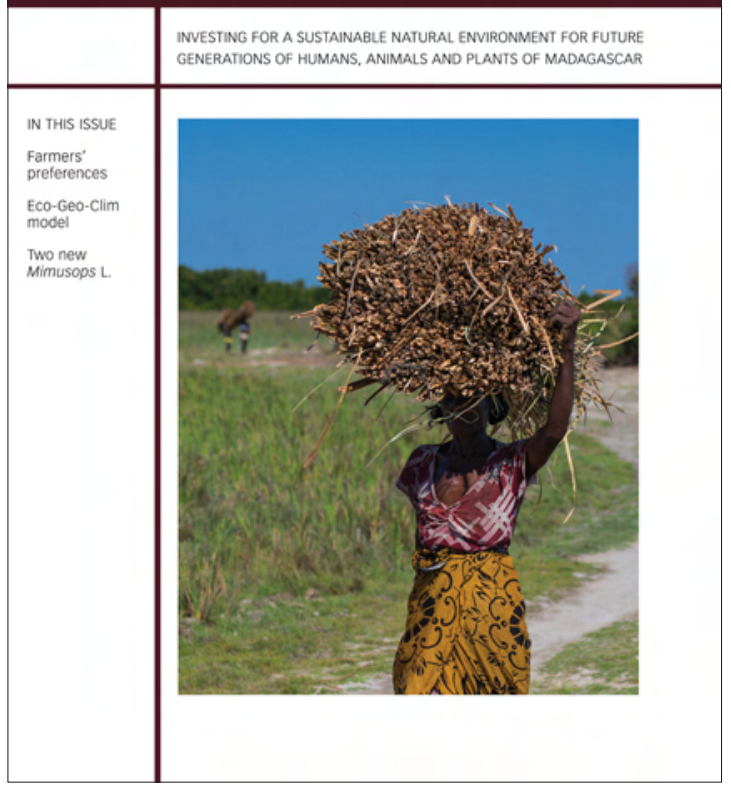

Madagascar Conservation \& Development is the journal of Indian Ocean e-Ink. It is produced under the responsibility of this institution. The views expressed in contributions to MCD are solely those of the authors and not those of the journal editors or the publisher.

All the Issues and articles are freely available at http://www.journalmcd.com

Contact Journal MCD

info@journalmcd.net for general inquiries regarding MCD funding@journalmcd.net to support the journal

Madagascar Conservation \& Development Institute and Museum of Anthropology University of Zurich

Winterthurerstrasse 190

$\mathrm{CH}-8057$ Zurich, Switzerland

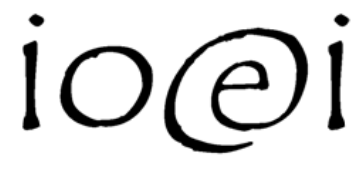

Indian Ocean e-Ink

Promoting African Publishing and Education www.ioeink.com
Missouri Botanical Garden (MBG)

Madagascar Research and Conservation Program BP 3391

Antananarivo, 101, Madagascar 
mena, ring-tailed vontsira], Galidictis fasciata [vontsira-fotsy, broad-striped vontsira], Salanoia concolor [vontsira-tsavoka, brown-tailed vontsira]), and three introduced carnivorans, (Viverricula indica [jabady, small Indian civet], Canis familiaris [amboa, domestic dog], and Felis catus [bosy, domestic cat]), are known to exist on the peninsula. This paper calls attention to an animal in the Masoala carnivoran assemblage known as the fitoaty (Figure 1). The taxonomic identity of the fitoaty is currently unknown. It may be a melanistic feral domestic cat (Felis catus), a melanistic wildcat (Felis silvestris), or a distinct species unique to the region.

Felis were introduced to Madagascar by the $17^{\text {th }}$ century (Flacourt 1658, Kerr 1792). Both domesticated and wild or feral cats exist on the island today, but whether these represent a single species (Felis catus) or two (F. catus and F. silvestris) remains unknown. The relationship of Madagascar's wild living cats to the African wildcat (Felis silvestris cafra) is also unknown. Until further genetic research has been completed, there will continue to be great uncertainty about the taxonomic identity of Madagascar's wild living cats.

The morphology of wild living cats in Madagascar has been described as "easily distinguishable from domestic cats" (Brockman et al. 2008: 137). Their pelage is similar to that of wild living cats elsewhere in the world (Goodman et al. 2003; for a description of typical pelage cf. Daniels et al. 1998) and is characterized by an underlying agouti/tawny brown coat with overlying dark grey tabby patterning, a dark banded tail, and lack of variation in coat pattern (Daniels et al. 1998, Goodman et al. 2003, Brockman et al. 2008). They have also been described as larger than domestic cats (both in overall weight, height, and length), and as exhibiting significant sexual dimorphism (males twice as large as females) (Goodman et al. 2003, Brockman et al. 2008). While most wild living cats around the world have tabby coats, some wildcat (Felis silvestris) populations in Scotland exhibit a variety of coat patterns including "primarily

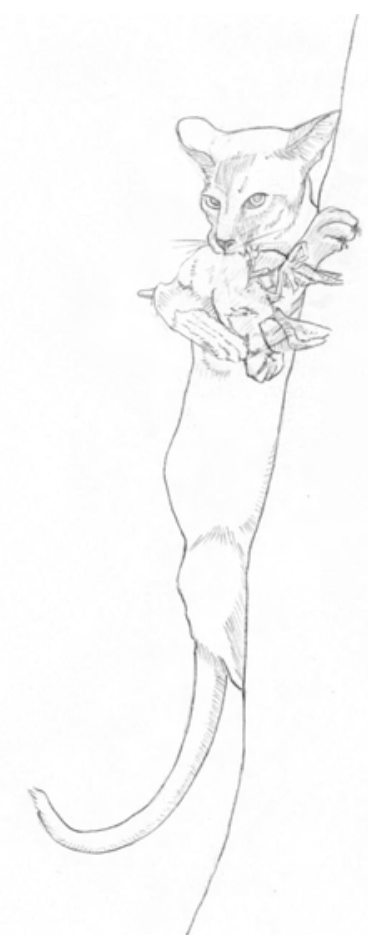

FIGURE 1. Artist's rendering drawn from local Malagasy descriptions and confirmed likeness of a fitoaty. (C) Joel Borgerson black" (Daniels et al. 1998: 237). Hybridization with domestic cats may have been responsible for increasing this color variation, but in Madagascar, differences between wild living cat and domestic cat ranging patterns are thought to "segregate the stocks" (Brockman et al. 2008: 137).

Felis inhabit numerous natural habitats and national parks within Madagascar (e.g., Goodman et al. 1993, Dollar et al. 2007, Brockman et al. 2008, Farris et al. 2012, Gerber et al. 2012ab), but these wild living cats may be more common in the arid western half of the country (Goodman et al. 2003). They have been primarily found in secondary, fragmented, or disturbed forests and in wooded grasslands (Dollar et al. 2007, Gerber et al. 2012b), but can range into deeply forested areas or near villages when crossing them in order to access preferred habitat types (Dollar, unpub. data). They have been variously described as: cathemeral (Gerber et al. 2012a); mostly crepuscular or nocturnal, with some diurnal activity (Dollar, unpub. data); or increasing their diurnal activity only when they have litters (Ratsirarson et al. 2001, Brockman et al. 2008).

Felis has been shown to negatively impact endemic Malagasy fauna in many ways. Elsewhere, wild living cats are solitary, and have an opportunistic diet of birds, small-medium sized rodents, small reptiles, and amphibians (Malo et al. 2004, Lozano et al 2006). Censuses in Madagascar show reduced numbers of understory bird and small rodents within wild living Felis sp. ranges (Dollar et al. 2007). Felis is known to predate large lemurs such as Lemur catta and Propithecus verreauxi, when these lemurs descend to the ground (Goodman et al 1993, Ratsirarson et al. 2001, Gould and Sauther 2007, Brockman et al. 2008). Felis also negatively impact sympatric native Malagasy carnivorans (Gerber et al. 2012a). In the southeast, Galidia elegans is negatively correlated with Felis abundance, potentially due to interspecific temporal and dietary competition (Gerber et al. 2012ab), and in the northeast Salanoia concolor has been found to be absent at sites where wild living Felis occur (Farris et al. 2012). Felis may also transmit diseases to Cryptoprocta ferox (Dollar 2006).

More research on the little known fitoaty is needed, as this animal is currently excluded from discussions on Masoala ecology, yet it may have substantial impact on the Masoala ecosystem. The purpose of this paper is to (i) report preliminary observations on the fitoaty collected on the Masoala peninsula, and (ii) describe its distribution and habits based on local knowledge.

\section{METHODS}

DATA COLLECTION. This study was conducted over

five months in 36 villages on the western portion of the Masoala peninsula by the author and her field assistant Rajaona Delox. Two methods were employed: (i) extensive and detailed semi-structured interviews in a single village; and (ii) rapid indirect assessment survey interviews of village presidents over a broad geographic range.

single Site Interviews: The author has been working in the region since 2007 and speaks the native dialect of Betsimisaraka. Semi-structured interviews of at least one individual from $100 \%$ of households $(n=32)$ in the village of Ambodiforaha (population 118) were used, where the author first saw the fitoaty. 
Interviewees were shown photographs of all known Masoala carnivorans and asked if they: (1) were aware of an animal called fitoaty; (2) had ever caught/eaten, or would potentially eat one; (3) if they had or would not, to explain why; (4) if they had ever seen one personally; and if yes, to describe (5) the morphology of the animal; and (6) the location, time, and circumstances of their sighting.

Rapid Indirect Assessment: Village presidents of all known communities bordering the western edge of the Masoala National Park $(n=36)$ were interviewed by R. Delox, a trained and experienced field assistant native to the peninsula. Interviewees were asked the full set of questions that the author asked about fitoaty at single site interviews, as well as the number of villagers who had seen the fitoaty. These quick coarse-grain preliminary data were collected to estimate the fitoaty's potential range and may not reflect actual abundance. Village locations, altitude, and population size were also recorded.

DATA ANALYSIS. The relationships between the

percentage of people in a community who had seen a fitoaty and village characteristics were examined using a Pearson correlation matrix. Percentages were selected over the raw number of villagers to control for the possibility that larger communities may have more people who have seen the fitoaty simply because of their size. Four variables were examined as potential predictors of the number of villagers who had seen fitoaty: (1) village distance from the Masoala National Park; (2) village distance from the ocean (Antongil Bay); (3) village altitude; and (4) village population size. Village distance from the Masoala National Park was ranked from 1-3, $1=$ inside the park, $2=$ adjacent to the park $(\leq 2 \mathrm{~km})$, and $3=$ not adjacent to the park $(>2 \mathrm{~km})$. Two kilometers from the park was selected because this distance is easily travelled to and from by villagers on the Masoala before returning home for a meal (typical practice). Village distance from the ocean was ranked from 1-3, $1=$ on the coast, $2=\leq 5 \mathrm{~km}$ from the coast, and $3=>5 \mathrm{~km}$ from the coast. Village altitude was ranked from $1-3,1=<400 \mathrm{~m}$ above sea level , $2=400-700 \mathrm{~m}$ a.s.l, and $3=>700 \mathrm{~m}$ a.s.l.

These four predictor variables were selected because they can be remotely determined with ease by future researchers when determining where to conduct extensive surveys or research on the fitoaty. Village distance from the Masoala National Park and the Antongil Bay, population size, and village altitude may also provide preliminary information on fitoaty habitat constraints, tolerance for anthropogenic activity and/ or disturbance, and/or patterns in fitoaty range.

\section{RESULTS}

In 2011 the author witnessed a medium-sized melanistic carnivoran crossing a village trail just outside the Masoala National Park boundary. The sighting occurred at approximately 15:00h, in a transitional area of primary and secondary forest, $\sim 1.2$ kilometers south of the remote village of Ambodiforaha (at approximately E049 $\left.57^{\prime} 35^{\prime \prime}, \mathrm{S} 15^{\circ} 43^{\prime} 26^{\prime \prime}\right)$. Further investigation and interviews of local people in 36 villages within the western half of the Masoala peninsula confirmed the existence of a black Felis like carnivoran. The animal is widely known throughout the western half of the peninsula, and is called fitoaty in the regional dialect of Betsimisaraka Malagasy.

Local people describe fitoaty morphology as feline. It is approximately 3-4 kg in size, muscular, lean, with a uniform, short, glossy black pelage. This description is consistent with the author's sighting. It is said to have red-orange eyes. There is apparently a widespread population of this animal on the peninsula, yet its specific taxonomic identity and ecological impact is unknown and requires further investigation.

SINGLE SITE INTERVIEWS. Ninety-four percent of

interviewees had heard of an animal called the fitoaty and $22 \%$ had seen the animal. The number of sightings per participant ranged from 1-3; sightings occurred 1-25+ years prior to the interview. All were of single animals traveling during daylight. Fitoaty have been seen in both remote undisturbed forests and in fragmented forests, but never in or near the village. Most sightings were of the fitoaty running across or near a forest trail. Interviewees consistently described fitoaty morphology as 'domestic cat-like', with the exception of (1) its larger size, estimated at 3-4 kg, (2) its greater muscularity and leaner build, (3) its uniformly short glossy pelage of solid deep black, and (4) its red-orange eyes. Even people who had repeatedly seen the fitoaty considered it rare.

Fitoaty meat is reported to be mahimbo (having bad smell). No one interviewed had ever eaten fitoaty and $88 \%$ claimed unwillingness to eat the animal, even if they caught it, either because of personal preference or fady (complex familial or individual taboo). When asked to explain their disinclination to eat the animal, interviewees described the fitoaty's physical similarity to a domestic cat and the inedibility of the meat (believed to be either poisonous or sickening). Trappers do not build traps to catch fitoaty and believe that fitoaty outsmart existing carnivore traps targeting the similarly-sized Fossa fossana and Viverricula indica. Only one trapper reported knowing someone (deceased) who had inadvertently caught the animal.

One participant reported that fifteen years ago, near his remote forest home, fitoaty would steal chickens from his land to feed its young. He found a fitoaty with four young in a lalogno tree hole filled with dried brush two meters above the ground. Throughout the day, the fitoaty brought birds (including a Streptopelia picturata [domóhina, Madagascar turtle dove] and a Centropus toulou [monjo, Madagascar coucal]) to the tree hole.

RAPID INDIRECT ASSESSMENT. Presidents of 15 of the

36 villages surveyed reported at least one member of their village who had seen a fitoaty (Figure 2). Eighty-six individuals were reported to have seen the animal (range $=2-15$ individuals per village). Descriptions of the fitoaty were consistent with those provided by single-site interviewees. Even in villages where sightings had occurred, they were relatively rare, only $1-20 \%$ of the villagers having seen the animal. Fitoaty sightings are not significantly correlated with village size $(r=-0.09, P=$ $0.62)$, distance from the ocean $(r=-0.53, P=0.76$ ), or village altitude $(r=0.27, P=0.12)$. While fitoaty were seen by individuals in villages surrounded by both fragmented and primary forests, the percentage of individuals in each village reported to have seen a fitoaty was significantly negatively correlated with village distance from the Masoala National Park $(r=-0.39, P=0.018)$.

\section{DISCUSSION}

This is the first report of a feline-like animal, locally known as the fitoaty, on the Masoala peninsula. The name fitoaty means seven livers, and originates from a story of a man who unintentionally snared the animal, and upon processing it, discovered seven livers. However, snare trappers interviewed do not actually 


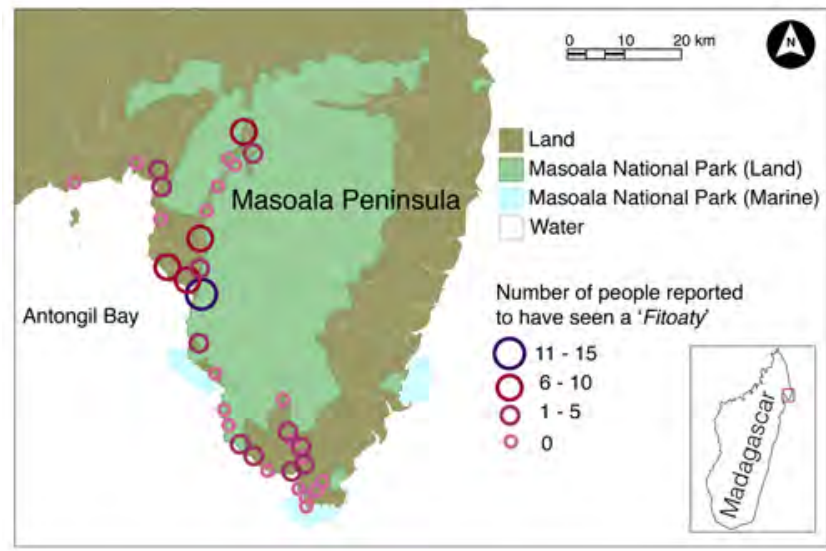

FIGURE 2. Rapid indirect assessment of fitoaty sightings on the Masoala peninsula.

believe that fitoaty have seven livers and fitoaty are currently not hunted or consumed on the peninsula.

Neither fitoaty eye color nor pelage matches that of previously described wild living cats in Madagascar (e.g., Goodman et al. 2003, Brockman et al. 2008). Among mammals elsewhere, the genetic material for different coat patterning often exists, but can be masked (Cieslak et al. 2011). It is possible that the fitoaty's unique coloration is due to a mutant or recessive allele already present in wild living cats, that has either been selected for on the peninsula, or fixed through genetic drift and reduced gene flow. The taxonomic identity of this animal is currently unknown. It may be a melanistic feral domestic cat, melanistic wildcat, or a distinct species unique to the region. Genetic testing is needed to determine the taxonomic identity of this, likely Felis sp. in the Masoala, and to clarify the identity of other Felis throughout Madagascar. Rigorous methods are also needed to establish the presence or absence of the fitoaty throughout the Masoala, and their potential impact on native species.

Unlike wild living cats elsewhere in Madagascar who have been shown to prefer secondary, fragmented, or disturbed forests and wooded grasslands (Dollar et al. 2007, Gerber et al. 2012b), fitoaty were most often seen close to the Masoala National Park. This may indicate a relatively low tolerance for forest disturbance and a significant presence of fitoaty within the park. Whatever its identity, the fitoaty has an unknown impact on the species protected within the Masoala National Park, Madagascar's last remaining lowland coastal rainforest. Considering the Masoala's unique role in Madagascar (summarized in Kremen et al. 1999, Kremen 2003), and the known negative impact of introduced carnivorans on Madagascar's native birds and rodents (Dollar et al. 2007), lemurs (Goodman et al 1993, Ratsirarson et al. 2001, Gould and Sauther 2007, Brockman et al. 2008), and carnivorans (Dollar 2006, Farris et al. 2012, Gerber et al. 2012b), the identity, range, and ecological impacts of the fitoaty warrant swift examination. Hopefully, this study will motivate such research.

\section{ACKNOWLEDGMENTS}

This project would have been impossible without the dedication of Malagasy research assistants Rajaona Delox and Elison Pascal and the generous support of the village of Ambodiforaha and 35 other Masoala communities. I am also grateful to Dr. Laurie R. Godfrey, Dr. Emilienne Rasoazanabary, and several anonymous reviewers who substantially improved this manuscript, Joel Borgerson for his illustration, Dr. Luke Dollar for his correspondence on melanistic carnivores, and to Madagascar National Parks and MICET for their continued support. This research was funded by grants from the Margot Marsh Biodiversity Foundation, Conservation International Primate Action Fund, Oregon Zoo Future for Wildlife Fund, and the International Primatological Society. University of Massachusetts, Amherst IACUC (2010-0010 and 2012-0028) and Human Subjects IRB (2010-0595) approved this research.

\section{REFERENCES}

Brockman, D. K., Godfrey, L. R., Dollar, L. J. and Ratsirarson, J. 2008. Evidence of invasive Felis silvestris predation on Propithecus verreauxi at Beza Mahafaly Special Reserve, Madagascar. International Journal of Primatology 29, 1: 135-152. (doi:10.1007/s10764-007-9145-5)

Cieslak, M., Reissmann, M., Hofreiter, M. and Ludwig, A. 2011. Colours of domestication. Biological Reviews 86 4:885-899. (doi:10.1111/j.1469185X.2011.00177.X)

Daniels, M. J., Balharry, D., Hirst, D., Kitchener, A. C. and Aspinall, R. J. 1998. Morphological and pelage characteristics of wild living cats in Scotland: implications for defining the 'wildcat'. Journal of Zoology 244, 2: 231-247. (doi:10.1111/j.1469-7998.1998.tb00028.x)

Dollar, L. J. 2006. Morphometrics, diet, and conservation of Cryptoprocta ferox. Ph.D. thesis, Duke University, Durham NC, USA.

Dollar, L. J., Ganzhorn, J. U. and Goodman, S. M. 2007. Primates and other prey in the seasonally variable diet of Cryptoprocta ferox in the dry deciduous forest of western Madagascar. In: Primate Anti-Predator Strategies. S. L. Gursky and K. A. I. Nekaris (eds.), pp 63-77. Springer, New York.

Farris Z.J., Kelly M.J., Karpanty S.M., Ratelolahy F., Andrianjakarivelo V., Holmes C. (2012) Brown-tailed vontsira Salanoia concolor (Eupleridae) documented in Makira Natural Park, Madagascar: new insights on distribution and camera-trap success. Small Carnivore Conservation $47: 82-86$.

Flacourt, E., de. 1658. Histoire de la Grande Isle Madagascar. INALCOKarthala, Paris.

Gerber, B. D., Karpanty, S. M. and Randrianantenaina, J. 2012a. Activity patterns of carnivores in the rain forests of Madagascar: implications for species coexistence. Journal of Mammalogy 93, 3: 667-676. (doi:10.1644/11-MAMM-A-265.1)

Gerber, B. D., Karpanty, S. M. and Randrianantenaina, J. 2012b. The impact of forest logging and fragmentation on carnivore species composition, density and occupancy in Madagascar's rainforests. Oryx 46, 3: 414-422. (doi:10.1017/S0030605311001116)

Goodman, S. M., Ganzhorn, J. U. and Rakotondravony, D. 2003. Introduction to the mammals. In: The Natural History of Madagascar. S. M. Goodman and J. P. Benstead (eds.), pp 1159-1186. The University of Chicago Press, Chicago.

Goodman, S. M., O'Connor, S. and Langrand, O. 1993. A review of predation on lemurs: Implications for the evolution of social behavior in small, nocturnal primates. In: Lemur Social Systems and Their Ecological Basis. J. U. Ganzhorn and P. M. Kappeler (eds.), pp 51-66. Plenum Press, New York.

Gould, L. and Sauther, M. L. 2007. Anti-predator strategies in a diurnal prosimian, the ring-tailed lemur (Lemur catta), at the Beza Mahafaly Special Reserve, Madagascar. In: Primate Anti-Predator Strategies. S. L. Gursky and K. A. I. Nekaris (eds.), pp 275-288. Springer, New York

Hawkins F. 2012. Recent records of brown-tailed vontsira Salanoia concolor (Eupleridae) in Masoala National Park, Madagascar. Small Carnivore Conservation 47: 11-13.

Kerr, R. 1792. Animal kingdom. Class I. Mammalia. W. Creech, Edinburgh.

Kremen C. 2003. The Masoala peninsula. In: The Natural History of Madagascar. S. M. Goodman and J. P. Benstead (eds.), pp. 1459-1466. The University of Chicago Press, Chicago. 
Kremen, C., Razafimahatratra, V., Guillery, R. P., Rakotomalala, J., Weiss, A. and Ratsisompatrarivo, J.-S. 1999. Designing the Masoala National Park in Madagascar based on biological and socioeconomic data. Conservation Biology 13, 5: 1055-1068. (doi:10.1046/j.15231739.1999.98374.x)

Lozano, J., Moleon, M. and Virgos, E. 2006. Biogeographical patterns in the diet of the wildcat, Felis silvestris Schreber, in Eurasia: factors affecting the trophic diversity. Journal of Biogeography 33, 6:1076-1085. (doi:10.1111/j.1365-2699.2006.01474.x)

Malo, A. F., Lozano, J., Huertas, D. L. and Virgos, E. 2004. A change of diet from rodents to rabbits (Oryctolagus cuniculus). Is the wildcat (Felis silvestris) a specialist predator? Journal of Zoology 263, 4:401-407. (doi:10.1017/S0952836904005448)

Ratsirarson, J., Randrianarisoa, J., Ellis, E., Emady, R. J., Efitroarany, Ranaivonasy, J., Razanajaonarivalona, E. H. and Richard, A. F. 2001. Beza Mahafaly: Ecologie et réalités socio-économiques, Recherches pour le Développement, Série Sciences Biologiques No. 18, CIDST. Antananarivo, Madagascar.

Yoder, A. D., Burns, M. M., Zehr, S., Delefosse, T., Veron, G., Goodman, S. M. and Flynn, J. J. 2003. Single origin of Malagasy carnivora from an African ancestor. Nature 421:734-737. (doi:10.1038/nature01303) 